\title{
Editorial
}

\section{腎臓病と代謝障害 一内科医に求められる基礎と応用一}

〔日内会誌 $104 ： 901 ９ 05 ， 2015]$

Key words 代謝異常, CKD，AKI，ガイドライン

\section{はじめに}

成人体重の $60 \%$ を占める体液の質的, 量的な 恒常性を維持するうえで, 腎臓は最終的な出納 を決定するという重要な役割を果たしている. 腎臓機能が低下する原因は多様であるが，どの ような原疾患があろうとも, 進行した状態にお いては，体液組成を中心とした，共通かつ複数 の代謝異常が生じる。しかも，それぞれの代謝 異常自体が腎障害の進行因子として作用し, 同 時に他臓器の障害も進行させることが多い.

慢性腎臓病 (chronic kidney disease : CKD) に 代表される腎臓病は, 人口の高齢化とともに増 加しており，今や成人の 8 人に 1 人が該当する といわれている。したがって, 腎臓病を有しな がら，他疾患を併せもつ国民は多く，日常の診 療において腎障害に伴う代謝異常の病態を理解 し対策を講じることは, 内科医にとって必要な ことであろう。
そこで，今回は“腎臓病に伴う代謝異常”と いうテーマで, 内科医に求められる基礎と応用 について, 最近の知見を交えて解説していただ くことにした。特に, 日常臨床上よく観察され る異常であり，かつ腎臓病患者特有の問題点も はらんでいるものとして，(1)水・ナトリウム， (2)糖, (3)脂質, (4)尿酸, (5)酸塩基, (6)骨カルシ ウム, (7)リン, (8)鉄・赤血球, そして(9)薬郕代 謝の9 項目を取り上げる.

“腎臓病”には多様な原因と病態が含まれ, 上 記 9 項目があらゆる腎藏病で同様に生じるわけ ではないが，共通する点が多い。それらを一括 して理解することによって, 共通の対策や病期 の把握を可能とした概念が, 慢性腎臓病と急性 腎障害（acute kidney injury：AKI）である。本 稿では, 各項目での理解を深める補助として, CKD とAKIについて改めて概説する.なお, CKD, AKIともに，それぞれ最近の本会誌で記述され ている（2012 年 101 巻 5 号, 2013 年 102 巻 5 
号). 詳細はそちらも参考にしていただきたい.

\section{1. 慢性腎臓病（CKD）}

CKDが注目される理由は2つある.1つは, 透 析療法や腎移植などの腎代替療法を必要とする 未期腎不全（end stage renal disease : ESRD）患 者数の増加である. 我が国では 2013 年末で 31 万 4,000人が透析治療を受けており, 増加傾向 は止まっていない.これは日本国内のみでなく 世界的な傾向であり, 多くの患者のQOL (quality of life）を低下させるだけでなく, 経済的・人的 に多大なコストを要している。しかも, 腎不全 原疾患としてのCKDは, 高血圧, 糖尿病などの 生活習慣病や加齢など, 今後も増え続けること が確実な背景因子と深い関連がある。したがっ て, 増え続けるESRDの発生を抑えるためには, 医師のみでなく, 社会全体の予防対策と早期発 見に関する取り組みが必要である.

2つ目は, 未期腎不全のリスクのみではなく, 心血管事故や死亡あるいは入院のリスクファク ターとしてのCKDの重要性が, 多くの疫学研究 により明らかにされていることである1,2).すな わち, CKDはその数の多さと腎藏以外の健康障 害の危険因子として, 国民の健康を务かす重要 な疾患として位置づけられる。

CKDの概念・分類は, 複雑多様な腎疾患を, “慢性に経過する腎臓の異常”として一括りに 定義することで, 医療関係者, 行政, 患者を含 む全ての関係者が共通の認識, 治療目標を持つ ことを初めて可能にした.つまり, 診断や定義 が簡便であり, 腎機能やステージ, 治療目標が 明確になった点で意義が大きい.

2002 年頃に米国腎臓学会から始まったこの 動きは各国に広がり, 地球規模で展開され, 国 際腎臓学会 (International Society of Nephrology : ISN) やKDIGO (Kidney Disease Improving Global Outcome）などの組織が本格的なCKD対 策を取り始めた。日本では日本腎臓学会, 日本
透析医学会, 日本高血圧学会, 日本糖尿病学会 が協力して, 患者数の把握と対策の提言をまと めた（日本腎蔵学会CKD診療ガイド 2007 年). その後, 共通の分類基準をもって疾患を診るこ とにより, 多くの臨床データが蓄積され, さら に蓄積されたエビデンスに基づいて改訂が行わ れた。最新のものとしては,「CKD診療ガイド $2012\lrcorner^{3)}$, およびより専門医向けの「エビデンス に基づくCKD診療ガイドライン 2013」4)が発刊 されている. 表 1 にCKDの重症度分類を示す. この特徴は, 糖尿病の有無で分けたこと, 腎機 能（GFR）に加えて蛋白尿によっても分類した こと，ステージ3を2つに分けたことである. その分類の根拠は, 表 2 にCKDにおける心血管 死亡と末期腎不全のステージ別オッズ比を示す ように明確である.

\section{2. 急性腎障害 (AKI)}

何らかの急性の腎機能低下は入院患者の 4 $5 \%$, ICU（intensive care unit）入室患者の 20\%

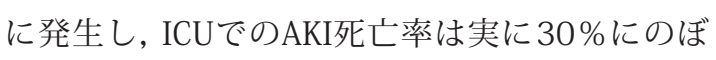
る.しかし, 統一した定義・診断基準がないた め, 十分な臨床研究が進んでこなかった。 そこ で, 2004 年 にAcute Dialysis Quality Initiative （ADQI）がRIFLE分類を提唱した.これは血清ク レアチニンと尿量に基づいてAKIを定義してお り, 表3のように“Risk, Injury, Failure, Loss, ESRD”のそれぞれについて明確な判断基準を示 した点で, 意義深い. その後, 2005年にはAcute Kidney Injury Network（AKIN）が設立され， RIFLE分類をより簡便にした分類（いわゆる AKIN分類）を作成した（表4）.AKIをその原因 にかかわらず，「48時間以内に血清クレアチニ ン值が $0.3 \mathrm{mg} / \mathrm{d} 1$ 以上または $50 \%$ 以上の上昇, あるいは 6 時間以上にわたる $0.5 \mathrm{ml} / \mathrm{kg} /$ 時間以 下の尿量低下」と定義し程度により 3 段階に分 類している. 発症前の血清クレアチニン值が不 明な場合にも判断できること，わずかな血清ク 


\section{表1ＣKDの重症度分類}

\begin{tabular}{|c|c|c|c|c|c|c|}
\hline \multicolumn{2}{|c|}{ 原疾患 } & \multicolumn{2}{|c|}{ 蛋白尿区分 } & A1 & $A 2$ & A3 \\
\hline \multirow{2}{*}{\multicolumn{2}{|c|}{ 糖尿病 }} & \multirow{2}{*}{\multicolumn{2}{|c|}{$\begin{array}{c}\text { 尿アルブミン定量 } \\
\text { (mg/日) } \\
\text { 尿アルブミン/Cr 比 } \\
(\mathrm{mg} / \mathrm{g} C \mathrm{r})\end{array}$}} & 正常 & 微量アルブミン尿 & 顕性アルブミン尿 \\
\hline & & & & 30 未満 & $30 \sim 299$ & 300 以上 \\
\hline \multirow{2}{*}{\multicolumn{2}{|c|}{$\begin{array}{l}\text { 高血圧 } \\
\text { 腎炎 } \\
\text { 多発性囊胞腎 } \\
\text { 移植腎 } \\
\text { 不明 } \\
\text { その他 }\end{array}$}} & \multirow{2}{*}{\multicolumn{2}{|c|}{$\begin{array}{c}\text { 尿蛋白定量 } \\
(\mathrm{g} / \text { 日) } \\
\text { 尿蛋白/Cr 比 } \\
(\mathrm{g} / \mathrm{gCr})\end{array}$}} & 正常 & 軽度蛋白尿 & 高度蛋白尿 \\
\hline & & & & 0.15 未満 & $0.15 \sim 0.49$ & 0.50 以上 \\
\hline \multirow{6}{*}{$\begin{array}{l}\text { GFR区分 } \\
(\mathrm{mL} / \text { 分/ } \\
\left.1.73 \mathrm{~m}^{2}\right)\end{array}$} & G1 & $\begin{array}{l}\text { 正常または } \\
\text { 高値 }\end{array}$ & $\geqq 90$ & & & \\
\hline & G2 & $\begin{array}{l}\text { 正常または } \\
\text { 軽度低下 }\end{array}$ & $60 \sim 89$ & & & \\
\hline & G3a & $\begin{array}{l}\text { 軽度〜 } \\
\text { 中等度低下 }\end{array}$ & $45 \sim 59$ & & & \\
\hline & G3b & $\begin{array}{l}\text { 中等度〜 } \\
\text { 高度低下 }\end{array}$ & $30 \sim 44$ & & & \\
\hline & G4 & 高度低下 & $15 \sim 29$ & & & \\
\hline & G5 & $\begin{array}{l}\text { 末期腎不全 } \\
\text { (ESKD) }\end{array}$ & $<15$ & & & \\
\hline
\end{tabular}

重症度は原疾患・GFR区分・蛋白尿区分を合わせたステージにより評価する.CKDの重症度は死亡，末期腎不全， 心血管死亡発症のリスクを緑口のステージを基準に，黄、，オレンジロ，赤口の順にステージが上昇するほど リスクは上昇する

(KDIGO CKD guideline 2012を日本人用に改変)

文献3より転載

表2ＣKDにおける心血管死亡と末期腎不全のステージ別オッズ比

\begin{tabular}{|c|c|c|c|c|}
\hline \multicolumn{5}{|c|}{ 心血管死亡 } \\
\hline & $\begin{array}{l}\text { ACR } \\
<10\end{array}$ & $\begin{array}{c}\text { ACR } \\
10 \sim 29\end{array}$ & $\begin{array}{c}\text { ACR } \\
30 \sim 299\end{array}$ & $\begin{array}{c}\text { ACR } \\
\geqq 300\end{array}$ \\
\hline $\begin{array}{l}\text { eGFR } \\
\geqq 105\end{array}$ & 0.9 & 1.3 & 2.3 & 2.1 \\
\hline $\begin{array}{l}\text { eGFR } \\
90 \sim 104\end{array}$ & Ref & 1.5 & 1.7 & 3.7 \\
\hline $\begin{array}{l}\text { eGFR } \\
75 \sim 89\end{array}$ & 1.0 & 1.3 & 1.6 & 3.7 \\
\hline $\begin{array}{l}\text { eGFR } \\
60 \sim 74\end{array}$ & 1.1 & 1.4 & 2.0 & 4.1 \\
\hline $\begin{array}{l}\text { eGFR } \\
45 \sim 59\end{array}$ & 1.5 & 2.2 & 2.8 & 4.3 \\
\hline $\begin{array}{l}\text { eGFR } \\
30 \sim 44\end{array}$ & 2.2 & 2.7 & 3.4 & 5.2 \\
\hline $\begin{array}{l}\text { eGFR } \\
15 \sim 29\end{array}$ & 14 & 7.9 & 4.8 & 8.1 \\
\hline
\end{tabular}

$\mathrm{ACR}:$ 尿アルブミン/Cr比 $(\mathrm{mg} / \mathrm{gCr})$ Ref : reference

末期腎不全

\begin{tabular}{l|c|c|c|c|} 
& $\begin{array}{c}\text { ACR } \\
<10\end{array}$ & $\begin{array}{c}\text { ACR } \\
10 \sim 29\end{array}$ & $\begin{array}{c}\text { ACR } \\
30 \sim 299\end{array}$ & $\begin{array}{c}\text { ACR } \\
\geqq 300\end{array}$ \\
\hline $\begin{array}{l}\text { eGFR } \\
\geqq 105\end{array}$ & Ref & Ref & 7.8 & 18 \\
\hline $\begin{array}{l}\text { eGFR } \\
\text { 90 104 }\end{array}$ & Ref & Ref & 11 & 20 \\
\hline $\begin{array}{l}\text { eGFR } \\
\text { 75 } \sim 89\end{array}$ & Ref & Ref & 3.8 & 48 \\
\hline $\begin{array}{l}\text { eGFR } \\
\text { 60 74 }\end{array}$ & Ref & Ref & 7.4 & 67 \\
\hline $\begin{array}{l}\text { eGFR } \\
\text { 45 59 }\end{array}$ & 5.2 & 22 & 40 & 147 \\
\hline $\begin{array}{l}\text { eGFR } \\
\text { 30 44 }\end{array}$ & 56 & 74 & 294 & 763 \\
\hline $\begin{array}{l}\text { eGFR } \\
15 \sim 29\end{array}$ & 433 & 1,044 & 1,056 & 2,286 \\
\hline
\end{tabular}

(Levey AS. Kidney Int 2011；80；17-28. より引用，改変) 文献3より転載 
表3 RIFLE分類

\begin{tabular}{|c|c|c|}
\hline & $\begin{array}{c}\text { 血清クレアチニン值 (Scr) } \\
\text { 糸球体濾過量 (GFR) }\end{array}$ & 尿量 \\
\hline RISK & $\begin{array}{c}\text { Scr が } 1.5 \text { 倍以上 } \\
\text { あるいは } \\
\text { GFR 25\% 以上低下 }\end{array}$ & $0.5 \mathrm{ml} / \mathrm{kg} /$ 時間未満が 6 時間以上 \\
\hline Injury & $\begin{array}{c}\text { Scr が } 2 \text { 倍以上 } \\
\text { あるいは } \\
\text { GFR50\% 以上低下 }\end{array}$ & $0.5 \mathrm{ml} / \mathrm{kg} /$ 時間未満が 12 時間以上 \\
\hline Failure & $\begin{array}{c}\text { Scr が } 3 \text { 倍以上 } \\
\text { あるいは } \\
\text { GFR75\% 以上低下 } \\
\text { あるいは } \\
\text { Scr } 4 \mathrm{mg} / \mathrm{dl} \text { 以上で } 0.5 \mathrm{mg} / \mathrm{dl} \text { 以上の上昇 }\end{array}$ & $\begin{array}{c}0.3 \mathrm{ml} / \mathrm{kg} / \text { 時間未満が } 24 \text { 時間以上 } \\
\text { あるいは } \\
\text { 無尿が } 12 \text { 時間以上 }\end{array}$ \\
\hline Loss & \multicolumn{2}{|c|}{ 腎機能の完全喪失 4 週間以上 } \\
\hline ESRD & \multicolumn{2}{|c|}{ 末期腎不全 } \\
\hline
\end{tabular}

(文献5より改変引用)

\section{表4 AKIN分類}

\begin{tabular}{|c|c|c|}
\hline & 血清クレアチニン值 (Scr) & 尿量 \\
\hline Stage 1 & $\begin{array}{c}0.3 \mathrm{mg} / \mathrm{dl} \text { 以上の上昇 } \\
\text { あるいは } \\
\text { 前値の } 1.5-2.0 \text { 倍の上昇 }\end{array}$ & $0.5 \mathrm{ml} / \mathrm{kg} /$ 時間未満が 6 時間以上 \\
\hline Stage 2 & 2.0-3.0 倍の上昇 & $0.5 \mathrm{ml} / \mathrm{kg} /$ 時間未満が 12 時間以上 \\
\hline Stage 3 & $\begin{array}{c}3.0 \text { 倍以上の上昇 } \\
\text { あるいは } \\
\text { Scr } 4.0 \mathrm{mg} / \mathrm{dl} \text { 以上で } 0.5 \mathrm{mg} / \mathrm{dl} \text { 以上の上昇 } \\
\text { あるいは } \\
\text { 腎代替療法の実施 }\end{array}$ & $\begin{array}{c}0.3 \mathrm{ml} / \mathrm{kg} / \text { 時間未満が } 24 \text { 時間以上 } \\
\text { あるいは } \\
\text { 無尿が } 12 \text { 時間以上 }\end{array}$ \\
\hline
\end{tabular}

（文献5より改变引用）

表5 KDIGO AKI分類

\begin{tabular}{|c|c|c|}
\hline & 血清クレアチニン值（Scr） & 尿量 \\
\hline Stage 1 & $\begin{array}{c}\text { 前値の 1.5-1.9 倍の上昇（7 日以内） } \\
\text { あるいは } \\
0.3 \mathrm{mg} / \mathrm{dl} \text { 以上の上昇（48 時間以内） }\end{array}$ & $0.5 \mathrm{ml} / \mathrm{kg} /$ 時間未満が 6-12 時間 \\
\hline Stage 2 & 2.0-2.9 倍の上昇 & $0.5 \mathrm{ml} / \mathrm{kg} /$ 時間未満が 12 時間以上 \\
\hline Stage 3 & $\begin{array}{c}3.0 \text { 倍以上の上昇 } \\
\text { あるいは } \\
\text { Scr } 4.0 \mathrm{mg} / \mathrm{dl} \text { 以上 } \\
\text { あるいは } \\
\text { 腎代替療法の実施 } \\
\text { あるいは } \\
18 \text { 歳未満では GFR } 35 \mathrm{ml} / \mathrm{min} / 1.73 \mathrm{~m}^{2} \text { 未満 }\end{array}$ & $\begin{array}{c}0.3 \mathrm{ml} / \mathrm{kg} / \text { 時間未満が } 24 \text { 時間以上 } \\
\text { あるいは } \\
\text { 無尿が } 12 \text { 時間以上 }\end{array}$ \\
\hline
\end{tabular}

(文献 5 より改変引用)

レアチニン值の上昇でも診断基準を満たすたさらに, 2012年にKDIGOが上記両分類を統合し め，早期のAKIを検出できることが特徴である。 たAKIガイドラインを公表した（表5)5).AKIN 
分類に加え, “7日以内の血清クレアチニン值 1.5 倍以上の上昇”を加えたこと, ステージ3の定 義を見直したことが変更点として挙げられる. より実臨床に即した改訂であり, 有用性が高い と思われる。

\section{おわりに}

日常臨床上頻度が高い代謝異常について, “腎 臓病”の切り口で企画した。読者の皆様の診療 や教育研究の一助になれば幸いである. 本稿で はCKD, AKIともに最近のガイドラインについて
ごく簡単に触れたが, 詳細は参照元をご覧いた だきたい。また，それぞれ国内で改訂，あるい は新規作成作業がスタートしている，新たな基 準のもとで蓄積しつつあるエビデンスの集積, それを利用する側の理解により, 診療がさらに 進歩していくことが期待される.

著者のCOI (conflicts of interest) 開示: 成田一衛 ; 講演 料（MSD，ジェンザイムジャパン，第一三共，田辺三菱 製薬，ノバルティスファーマ，持田製薬），寄附金（ア ステラス製薬，協和発酵キリン，クレハ，ジェンザイム ジャパン，第一三共. 武田薬品工業，中外製薬）

\section{文献}

1) Go AS, et al : Chronic kidney disease and the risks of death, cardiovascular events, and hospitalization. N Engl J Med $351:$ 1296-1305, 2004.

2) Ninomiya $\mathrm{T}$, et al : Chronic kidney disease and cardiovascular disease in a general Japanese population : the Hisayama Study. Kidney Int 68 : 228-236, 2005.

3）日本腎臓学会編：CKD診療ガイド 2012 .

4）日本腎臓学会編：エビデンスに基づくCKD診療ガイドライン 2013.

5) The Kidney Disease : Improving Global Outcome : Clinical practice guideline on acute kidney injury 2012. Kidney Int Suppl $2: 1-138,2012$. 